\title{
Sikap Orang Tua dan Siswa Terhadap Penerapan Protokol Kesehatan 5M pada Pembukaan Sekolah Tatap Muka di Masa Pandemi COVID- 19
}

\section{Parents and Students Attitude Towards Appling 5M Health Protocols on the Open- ing of Face-To-Face School During COVID-19 Pandemic}

Ai Evi ${ }^{1}$, Tuti Surtimanah ${ }^{1}$, Mila Mardotilah ${ }^{1}$

${ }^{1}$ Program Studi Sarjana Kesehatan Masyarakat, Sekolah Tinggi Ilmu Kesehatan Dharma Husada Bandung, 40282

*Korespondensi penulis:

tutisurtimanah@stikesdhb.ac.id
Diterima (Recieved)

Direvisi (Revised)

Diterima untuk diterbitkan (Accepted)
: 31 Desember 2021

: 31 Desember 2021

: 31 Desember 2021

\section{ABSTRAK}

Latar Belakang. COVID-19 menjadi pandemi global, kasus baru COVID-19 masih terus bertambah dan memengaruhi segala bidang kehidupan termasuk sekolah harus dilakukan secara daring. Ada keinginan membuka sekolah tatap muka langsung, untuk itu perlu diketahui sikap siswa dan orang tua terkait penerapan protokol kesehatan sebagai masukan untuk kebijakan.

Tujuan. identifikasi sikap orang tua dan siswa terhadap penerapan protokol kesehatan 5M pada pembukaan sekolah tatap muka dimasa pandemi COVID-19.

Metode. Menggunakan disain penelitian deskriptif komparatif dengan pendekatan cross sectional. Populasi siswa dan orang tua siswa Madrasah Aliyah 384 orang dengan sampel purposif 160 orang. Pengumpulan data dilakukan melalui kuesioner yang dikemas menggunakan Google form.

Hasil. Sebanyak $86,3 \%$ orang tua dan $82,5 \%$ siswa bersikap positif (mendukung) penerapan protokol kesehatan $5 \mathrm{M}$. Tidak adanya signifikan $(p$-value $=0,469)$ antara sikap orang tua dan siswa. Sebagian besar orang tua $(88,8 \%)$ dan siswa $(90 \%)$ menyatakan tidak ada hambatan dalam penerapan protokol kesehatan $5 \mathrm{M}$. Kesimpulan. Orang tua dan siswa sama-sama bersikap positif (mendukung) penerapan protokol kesehatan 5M pada pembukaan sekolah tatap muka di masa pandemic COVID-19. Orang tua diharapkan mendorong dan memfasilitasi siswa menerapkan 5M secara konsisten, sekolah mempersiapkan pengaturan pelaksanaan dan penyediaan sarana pendukung penerapan 5M.

Kata Kunci: penularan, masker, cuci tangan, jaga jarak, batasi bepergian

\section{ABSTRACT}

Background. COVID-19 is a global pandemic. New cases of COVID-19 continue to grow and affect all areas of life, including schools that must be conducted online. There is a desire to open a face-to-face school; therefore, it is necessary to know the attitudes of students and parents regarding the implementation of health protocols as input for the policy.

Objective. identify parents' and students' attitudes towards applying the 5M health protocol at the opening of face-to-face schools during the COVID-19 pandemic.

Method. used comparative descriptive research design with a cross-sectional approach. The population of parents and students are 384 people, with a purposive sample of 160 people. The data was collected using questionnaires packaged in Google forms.

Results. $86.3 \%$ of parents and $82.5 \%$ of students supported the implementation of the $5 M$. There was no significant difference ( $p$-value $=0.469)$ between parents' and students' attitudes. Most parents (88.8\%) and students (90\%) stated no obstacles in implementing the $5 M$ health protocol.

Conclusion: Parents and students positively support implementing the 5M health protocol at the opening of face-to-face schools during the COVID-19 pandemic. Parents should encourage and facilitate students to apply $5 M$ consistently, schools prepare implementation arrangements and provide supporting facilities for implementing $5 M$

Keywords: transmission, masks, wash hands, keep your distance, limit travel 


\section{LATAR BELAKANG}

Pandemi COVID-19 ditetapkan WHO 11 Maret 2020, sedangkan pemerintah Indonesia menetapkan Kedaruratan Kesehatan Masyarakat Corona Virus Disease 2019 (COVID-19) pada tanggal 11 Maret 2020. COVID-19 adalah penyakit baru, kunci pencegahannya adalah pemutusan rantai penularan dengan isolasi, deteksi dini, dan melakukan proteksi dasar. ${ }^{1}$ Pandemi berdampak pada bidang sosial maupun ekonomi masyarakat. Kebijakan Pembatasan Sosial Berskala Besar (PSBB) kemudian menjadi Pemberlakuan Pembatasan Kegiatan Masyarakat (PPKM) dan Adaptasi Kebiasaan Baru (AKB) diambil pemerintah sebagai upaya memutus penularan dan persebaran virus corona. Hal itu mendorong masyarakat berperilaku sesuai protokol kesehatan 5M. Berbagai aspek kehidupan masyarakat berubah secara cepat di masa pandemi ini. ${ }^{2}$

Salah satu bidang terdampak adalah bidang pendidikan. Selain meniadakan kegiatan pendidikan di sekolah, COVID-19 juga mengganggu kegiatan sosial, budaya, dan keagamaan. Penularan COVID-19 melalui kontak fisik juga menghalangi manusia dalam mengaktualisasikan dirinya sebagai mahkluk sosial untuk berinteraksi. ${ }^{3}$

Keluarga umumnya tidak terbiasa anakanaknya sekolah dari rumah. Hal ini mempengaruhi kebiasaan orang tua yang biasanya sibuk bekerja di luar rumah. Anakanak mengalami perubahan karena biasanya bertemu langsung dengan guru. Hal lain adalah bertambahnya pengeluaran keluarga untuk menyediakan kuota internet. $\mathrm{Di}$ daerah terpencil anak sekolah kebingungan, sebab infrastruktur informasi teknologi internet belum dapat diakses atau sangat terbatas. Penutupan sementara sekolah untuk menahan penularan COVID-19 berdampak pada siswa. Proses belajar langsung antara siswa dan guru tidak terjadi dan berdampak pada psikologis anak didik dan menurunnya kualitas keterampilan murid. ${ }^{4}$

Ada keinginan sekolah tatap muka secara terbatas segera dibuka karena berbagai dampak yang muncul, ada tiga komponen yang terkait yaitu siswa, orang tua dan guru. Guru memiliki peran penting dalam pembukaan sekolah tatap muka dimasa pandemi COVID-
19, karena guru sebagai fasilitator dan bertanggung-jawab dalam proses tatap muka. Pelaksanaan pembelajaran tatap muka ini perlu dilakukan secara berhati-hati, protokol kesehatan harus dipraktikkan secara ketat dan sekolah pun perlu mengupayakan pemulihan penurunan kemampuan siswa agar siswa memperoleh pembelajaran yang sesuai dengan kebutuhan mereka sehingga tidak semakin tertinggal. Selain itu orang tua maupun siswa mesti melakukan protokol kesehatan 5M bila pembelajaran tatap muka dilaksanakan.

Studi pendahuluan berupa wawancara terhadap beberapa siswa, mereka mengemukakan ingin sekolah tatap muka karena berbagai keterbatasan yang dirasakan sekolah secara daring. Beberapa orang tua menyatakan keberatan anaknya masuk sekolah tatap muka karena khawatir tertular COVID-19 saat bersekolah. Fokus penelitian adalah bagaimana sikap orangtua dan siswa untuk penerapan protokol kesehatan 5M bila sekolah tatap muka dilakukan, hal ini penting untuk bahan pengambilan kebijakan para pihak yang terkait.

Sikap terhadap kesehatan adalah bagaimana pendapat atau penilaian orang atau responden terhadap hal yang terkait dengan kesehatan, sehat, sakit dan faktor yang terkait dengan faktor risiko kesehatan. Sikap merupakan konsep yang sangat penting dalam komponen sosio-psikologis, karena merupakan kecenderungan bertindak, dan berpersepsi. Sikap adalah respon tertutup seseorang terhadap stimulus atau objek tertentu, yang sudah melibatkan faktor pendapat dan emosi yang bersangkutan (senang - tidak senang, setuju - tidak setuju, baik - tidak baik dan sebagainya). ${ }^{5}$ Dengan mengetahui sikap sebagai kecenderungan bertindak, maka sikap terhadap penerapan protokol kesehatan dijadikan arah duga bagaimana penerapannya dalam praktik. Dengan demikian bisa menjadi arah tindakan atau intervensi yang harus dilakukan sehingga praktik protokol kesehatan dilakukan saat sekolah tatap muka dibuka.

Berdasarkan uraian di atas dilakukan penelitian dengan tujuan menggali sikap orang tua dan siswa terhadap penerapan protokol kesehatan $5 \mathrm{M}$ pada pembukaan sekolah tatap muka dimasa pandemi COVID-19. 


\section{METODE}

Disain penelitian deskriptif komparatif dengan pendekatan cross sectional. Penelitian dilakukan di Madrasah Aliyah Al-Maarif Cianjur pada bulan Juli 2021. Populasi penelitian seluruh orang tua dan siswa Madrasah Aliyah Al-Maarif Cianjur kelas 11 dan 12 sebanyak 192 siswa. Teknik pengambilan sampel purposive yaitu yang memiliki gawai (handphone) dengan aplikasi WhatsApp (WA). Jumlah sampel 80 orang siswa dan 80 orang tua siswa (Contact rate 41,67\%). Hal ini lebih tinggi dari informasi pendahuluan dari guru, bahwa siswa yang memiliki gawai dengan aplikasi WhatsApp hanya 30\%.

Kriteria inklusi Siswa MA Al-Maarif kelas 11 dan 12, orang tua (ibu atau bapak) dari siswa MA Al-Maarif kelas 11 -12 dan memiliki gawai yang beraplikasi WhatsApp. Kriteria ekslusi adalah tidak bersedia ikut serta mengisi kuesioner melalui Google form yang dikirim serta tidak dapat mengisi Google form saat penelitian berlangsung karena ada halangan.

Instrumen berupa kuesioner berbentuk pertanyaan dengan jawaban berupa skala (sangat tidak setuju, tidak setuju, setuju, sangat setuju). Kuesioner sudah teruji valid dan reliabel dan dipakai pada penelitian terdahulu. ${ }^{6}$ Pertanyaan ditambahkan tentang kesediaan sekolah dilakukan tatap muka selama pandemi
COVID-19. Kuesioner dikemas dalam Google Form yang dikirim ke responden melalui aplikasi WhatsApp.

Selanjutnya data yang diperoleh di lakukan skrining kelengkapannya, diolah dan di analisis menjadi deskripsi sikap dan analisis beda (komparasi) sikap orang tua dan siswa menggunakan uji U Mann Whitney.

\section{HASIL}

Karateristik responden terdiri dari 80 orang tua siswa dan 80 siswa. Deskripsi sikap orang tua dan siswa dalam tabel 2. Secara keseluruhan, terdapat $82,5 \%$ siswa yang mendukung protokol $5 \mathrm{M}$ dan $86,3 \%$ orang tua yang mendukung protokol $5 \mathrm{M}$. Tabel 3 menyajikan kemungkinan hambatan penerapan protokol kesehatan $5 \mathrm{M}$ dan tabel 4 menunjukkan uji beda sikap antara siswa dan orang tua.

Tabel 1: Karakteristik responden $(n=160)$

\begin{tabular}{lcccc}
\hline \multicolumn{1}{c}{ Variabel } & \multicolumn{2}{c}{ Siswa } & \multicolumn{2}{c}{ Orang Tua } \\
& f & \% & f & \%o \\
\hline Jenis Kelamin & & & & \\
Laki-laki & 23 & 28.8 & 46 & 57.5 \\
Perempuan & 57 & 71.3 & 34 & 42.5 \\
Pendidikan Orang Tua & & & \\
SD & - & - & 61 & 76.3 \\
SMP & - & - & 12 & 15.0 \\
SMA & - & - & 7 & 8.8 \\
Kelas (siswa) & & & & \\
Kelas 11 & 26 & 32.5 & - & - \\
Kelas 12 & 54 & 67.5 & - & - \\
\hline
\end{tabular}

Tabel 2. Distribusi Frekuensi Sikap Siswa dan Orang Tua Terhadap Protokol Kesehatan 5M

\begin{tabular}{|c|c|c|c|c|c|c|c|c|}
\hline \multirow{3}{*}{ Variabel } & \multicolumn{4}{|c|}{ Siswa } & \multicolumn{4}{|c|}{ Orang Tua } \\
\hline & \multicolumn{2}{|c|}{ Kurang Mendukung } & \multicolumn{2}{|c|}{ Mendukung } & \multicolumn{2}{|c|}{ Kurang Mendukung } & \multicolumn{2}{|c|}{ Mendukung } \\
\hline & f & $\%$ & $\mathbf{f}$ & $\%$ & f & $\%$ & f & $\%$ \\
\hline Mungkin tertular & 26 & 32,5 & 54 & 67,5 & 18 & 22,5 & 62 & 77,5 \\
\hline Memakai masker & 0 & 0,0 & 80 & 100,0 & 0 & 0,0 & 80 & 100,0 \\
\hline Mencuci tangan & 1 & 1,2 & 79 & 98,8 & 0 & 0,0 & 80 & 100,0 \\
\hline Menjaga jarak & 1 & 1,2 & 79 & 98,8 & 0 & 0,0 & 80 & 100,0 \\
\hline Membatasi bepergian & 2 & 2,5 & 78 & 97,5 & 0 & 0,0 & 80 & 100,0 \\
\hline Menjauhi kerumunan & 1 & 1,2 & 79 & 98,8 & 0 & 0,0 & 80 & 100,0 \\
\hline Membuka kelas tatap muka & 2 & 2,5 & 78 & 97,5 & 2 & 2,5 & 78 & 97,5 \\
\hline Sikap (keseluruhan) & 14 & 17,5 & 66 & 82,5 & 11 & 13,8 & 69 & 86,3 \\
\hline
\end{tabular}

Tabel 3. Hambatan Penerapan Protokol Kesehatan 5M dari Siswa dan Orang Tua

\begin{tabular}{lcccccc}
\hline \multirow{2}{*}{ Kategori Hambatan } & \multicolumn{2}{c}{ Siswa } & \multicolumn{2}{c}{ Orang tua } & \multicolumn{2}{c}{ Siswa+Orang Tua } \\
& f & \% & f & \% & f & \% \\
\hline Ada hambatan & 8 & 10,0 & 9 & 11,2 & 17 & 10,6 \\
Tidak ada hambatan & 72 & 90,0 & 71 & 88,8 & 143 & 89,4 \\
\hline
\end{tabular}


Tabel 4. Uji Beda Sikap Siswa dan Orang Tua Terhadap Penerapan Protokol Kesehatan 5M pada Pembukaan Sekolah Tatap Muka di Masa Pandemi Covid-19

\begin{tabular}{lrrrrrrr}
\hline \multicolumn{1}{c}{ Variabel } & \multicolumn{3}{c}{ Siswa } & \multicolumn{3}{c}{ Orang Tua } & \multirow{2}{*}{ Nilai p $^{*}$} \\
& Mean & \multicolumn{1}{c}{ Med } & \multicolumn{1}{c}{ SD } & Mean & \multicolumn{1}{c}{ Med } & \multicolumn{1}{c}{ SD } & 0,469 \\
\hline Sikap (keseluruhan) & 21,87 & 21,50 & 1,883 & 21,85 & 21,00 & 2,081 & 0,460 \\
Mungkin tertular & 2,68 & 3,00 & 0,725 & 2,85 & 3,00 & 0,658 & 0,119 \\
Memakai masker & 3,26 & 3,00 & 0,443 & 3,19 & 3,00 & 0,393 & 0,257 \\
Mencuci tangan & 3,16 & 3,00 & 0,404 & 3,16 & 3,00 & 0,371 & 0,973 \\
Menjaga jarak & 3,15 & 3,00 & 0,393 & 3,14 & 3,00 & 0,347 & 0,805 \\
Membatasi bepergian & 3,09 & 3,00 & 0,363 & 3,13 & 3,00 & 0,333 & 0,521 \\
Menjauhi kerumunan & 3,16 & 3,00 & 0,404 & 3,11 & 3,00 & 0,318 & 0,364 \\
Buka kelas tatap muka & 3,39 & 3,00 & 0,539 & 3,28 & 3,00 & 0,551 & 0,209 \\
Hambatan & 1,89 & 2,00 & 0,309 & 1,89 & 2,00 & 0,309 & 0,798 \\
\hline
\end{tabular}

*Uji beda U Mann Whitney. Uji ini digunakan karena data berdistribusi tidak normal ( Uji normalitas distribusi Kolmogorov Smirnov $\mathrm{p}<0,05)$

\section{PEMBAHASAN}

Hasil penelitian menunjukan masih ada beberapa siswa dan orang tua yang memiliki sikap tidak mendukung di adakannya sekolah tatap muka, namun sebagian besar siswa dan orang tua memiliki sikap yang mendukung (positif) terhadap penerapan protokol kesehatan 5M dalam pembukaan sekolah tatap muka di masa pandemi COVID-19. Adanya sikap mendukung penerapan protokol kesehatan merupakan pertanda baik bahwa siswa dan orang tua menerapkan praktik $5 \mathrm{M}$ pada saatnya. Walaupun sebagian besar siswa dan orang tua menyatakan mendukung pembukaan sekolah tatap muka serta sebagian besar menyatakan tidak ada hambatan dalam penerapan protokol kesehatan, namun perlu pengaturan yang baik agar tidak terjadi kerumunan di sekolah, tetap menjaga jarak serta menggunakan masker dan cuci tangan. Perlu pengaturan dan penyediaan fasilitas agar protokol kesehatan dapat diterapkan misalnya penyediaan tempat cuci tangan di sekolah, pengaturan shift sekolah diantara siswa, serta ada pengawas yang mengingatkan siswa yang lupa atau lalai melakukan $5 \mathrm{M}$.

Aspek yang perlu mendapat perhatian adalah sikap terhadap kemungkinan tertular COVID-19, dimana masih cukup banyak yang tidak mendukung, artinya masih ada yang beranggapan bahwa COVID-19 tidak akan menular kepada dirinya atau ke orang lain.

Hasil penelitian ini sejalan dengan penelitian terdahulu terhadap mahasiswa Fakultas Kedokteran USU di Kota Medan tentang pengetahuan, sikap dan praktek pencegahan COVID-19, dimana diperoleh pengetahuan baik 92,23\%, sikap baik 94,04\% dan praktek baik 95,2\%. ${ }^{7}$ Penelitian lainnya menunjukan hasil pengetahuan responden mengenai COVID-19 sebanyak $71,2 \%$ baik, sikap responden sebanyak $74,6 \%$ positif dan perilaku responden menunjukan $59,2 \%$ baik. $^{8}$ Mengacu beberapa penelitian tersebut terlihat ada keselarasan antar tingkat pengetahuan, sikap dan praktek. Dengan demikian sikap yang positif atau mendukung pada penelitian ini diharapkan menjadi pertanda dalam praktiknya akan selaras pula yaitu tingginya tingkat praktik perilaku penerapan protkol kesehatan $5 \mathrm{M}$.

Masih adanya aspek sikap yang proporsi masih rendah yaitu sikap yang beranggapan bahwa COVID-19 tidak akan menular kepada dirinya atau ke orang lain, perlu mendapat perhatian. Penelitian terdahulu menemukan bahwa kondisi ini bisa memicu ketidakpatuhan melakukan upaya pencegahan protokol kesehatan 5M, disamping faktor lainnya. Banyak pelanggar yang kurang memahami bahaya penularan COVID-19 dan manfaat penerapan protokol kesehatan. Faktor lainnya yang mendorong ketidakpatuhan adalah motif ekonomi, sikap tidak peduli, merasa berpotensi rendah terhadap penularan virus, serta ketidakpercayaan kepada pemerintah yang mengeluarkan kebijakan dan pernyataan yang tidak konsisten. Sebagian masyarakat memaknai new normal sebagai kesempatan dan peluang beraktivitas kembali seperti saat sebelum pandemi merebak. Tidak adanya tokoh atau public figure yang dapat menjadi panutan menjadi kendala membangkitkan kesadaran warga dalam menerapkan protokol kesehatan 3M. ${ }^{9}$

Penelitian ini dilakukan di perdesaan dimana hasilnya sama dengan penelitian di perkotaan $^{7}$ yang menunjukan proporsi sikap positif - baik atau mendukung tinggi. Ada 
penelitian terdahulu yang menunjukan praktek pencegahan COVID-19 berbeda signifikan antara di perdesaan dan perkotaan, dimana kepatuhan masyarakat perdesaan lebih tinggi. ${ }^{10}$ Namun setelah dilakukan penyuluhan ternyata perubahan sikap masyarakat pedesaan dan perkotaan tidak berbeda. ${ }^{6}$ Akan tetapi, hal ini bertentangan dengan penelitian yang dilakukan oleh Fauzan Alfikrie et al. ${ }^{11}$ pada tahun 2021 dengan hasil tidak ada hubungan antara sikap dengan perilaku perilaku pencegahan COVID19 dengan nilai $p=0,06(>0,05)$.

Adapun faktor-faktor yang mempengaruhi sikap terhadap objek sikap antara lain pengalaman pribadi, pengaruh orang lain yang dianggap penting, pengaruh kebudayaan, media massa, lembaga keagamaan atau pendidikan dan kadangkala merupakan pernyataan yang didasari emosi yang berfungsi sebagai penyaluran frustasi atau pengalihan bentuk mekanisme pertahanan ego. ${ }^{5}$

Uji beda menunjukkan tidak ada beda signifikan ( $p$-value $>0,05)$ artinya orang tua maupun siswa siap untuk masuk sekolah tatap dengan sikap setuju menerapkan $5 \mathrm{M}$ seperti memakai masker, mencuci tangan, menjaga jarak, membatasi berpergian dan menjauhi kerumunan. Hasil penelitian ini juga menunjukkan bahwa orang tua dan siswa sebagain besar menyatakan tidak ada hambatan jika sekolah tatap muka dilaksanakan. Sekolah perlu melakukan pengaturan agar selalu memperhatikan siswanya menerapkan protokol kesehatan 5M. Sekolah tatap muka memang sangat baik, namun memang harus mematuhi atau patuh dengan protokol kesehatan 5M, kalau tidak mematuhi protokol kesehatan maka akan sangat mudah bisa tertular COVID-19 di sekolah.

Optimalisasi peran keluarga dalam menghadapi persoalan COVID-19 dapat ditingkatkan antaralain mendisiplinkan seluruh perilaku anggotanya, mengedukasi atau mendidik anak-anaknya supaya mematuhi protokol kesehatan yang ditetapkan pemerintah, mempersiapkan dan memenuhi kebutuhan hidup anggotanya, menanamkan kebiasaan pada anggotanya untuk senantiasa mempraktikan pola hidup dengan berolahraga secara rutin dan teratur, memelihara kesehatan mental keluarganya, saling memotivasi dan menguatkan secara sosial kemasyarakatan dalam upaya pemenuhan kebutuhan dasar manusia sebagai mahluk sosial. ${ }^{3}$

Beberapa hal yang perlu disiapkan sekolah bila mulai pembelajaran tatap muka antaralain penyiapan sarana cuci tangan dengan sabun dan air mengalir dengan jumlah yang disesuaikan dengan jumlah siswa, ada petugas yang mengukur suhu semua siswa maupun guru yang akan memasuki area sekolah. Selain itu pengaturan kelompok atau grup siswa yang masuk bergiliran sehingga kelas tidak penuh misalnya dibagi dalam 2-3 kelompok tergantung jumlah siswa per-kelas. Selanjutnya pengaturan ventilasi kelas, dengan jendela dan pintu yang bisa dibuka lebar sehingga terjadi aliran udara yang baik di kelas. Pemberian informasi kepada orang tua maupun siswa bahwa siswa yang mengalami gangguan kesehatan diharapkan tidak berangkat ke sekolah. Himbauan membawa masker cadangan untuk ganti di sekolah bila basah atau ada kerusakan misalnya putus tali. Sekolah juga perlu mengembangkan jejaring dalam melakukan pemeliharaan kesehatan siswa maupun guru serta personil sekolah lainnya, misalnya dengan puskesmas dimana sekolah tersebut berada termasuk dalam upaya vaksinasi COVID-19. ${ }^{12}$

Keterbatasan penelitian adalah pengumpulan data dilakukan melalui pengiriman Google form karena tidak bisa menjelaskan secara langsung apa yang dimaksud dalam pertanyaan kepada responden. Selain itu, respons rate hanya $41,67 \%$ karena tidak semua siswa memiliki gawai dengan aplikasi WhatsApp.

\section{KESIMPULAN}

Orang tua dan siswa sama-sama bersikap positif (mendukung) penerapan protokol kesehatan $5 \mathrm{M}$ pada pembukaan sekolah tatap muka di masa pandemic COVID-19. Tidak ada perbedaan signifikan antara sikap orangtua dan siswa.

\section{SARAN}

Orang tua diharapkan mendorong dan memfasilitasi siswa dalam menerapkan protokol kesehatan 5M secara konsisten. Sekolah mempersiapkan pengaturan pelaksanaan pembelajaran tatap muka di masa pandemi serta 
menyediakan sarana pendukung penerapan $5 \mathrm{M}$ di sekolah.

\section{UCAPAN TERIMA KASIH}

Penulis mengucapkan terima kasih kepada Ketua STIKes Dharma Husada Bandung atas dukungannya dalam menyelesaikan artikel ini.

\section{DAFTAR REFERENSI}

1. Kementerian Kesehatan Republik Indonesia. Pedoman Pencegahan Dan Pengendalian Corona Virus Disease (COVID19). Vol 5.; 2020. doi:10.33654/math.v4i0.299

2. Kemenkes RI. Pedoman Perubahan Perilaku. Pedoman Perubahan Perilaku Penanganan COVID-19. Published online 2020:1-60.

3. Santika IGNN. Optimalisasi Peran Keluarga Dalam Menghadapi Persoalan COVID-19: Sebuah Kajian Literatur. Jurnal Ilmu Ilmu Sos. 2020;6(2):127. doi:10.23887/jiis.v6i2.28437

4. Syah RH. Dampak COVID-19 pada Pendidikan di Indonesia: Sekolah, Keterampilan, dan Proses Pembelajaran. SALAM Jurnal Sosial dan Budaya Syari. 2020;7(5). doi:10.15408/sjsbs.v7i5.15314

5. Notoatmodjo S. Promosi Kesehatan Dan Perilaku Kesehatan. Rineka Cipta; 2014.

6. Surtimanah T, Hanifah, Hasna, Nataria N, Lfianita D, Audia SS, Mulyawan, Pratama, S IN. Penyuluhan Pencegahan COVID-19 Melalui Video Bagi Masyarakat Perdesaan dan Perkotaan. AS-SYIFA Jurnal Pengandian dan Pemberdaya Kesehatan Masyarakat. 2021; Volume. 2(1):43-53.

7. Lubis DAS. Hubungan Tingkat Pengetahuan dengan Sikap dan Perilaku terhadap Pencegahan Infeksi COVID19 Pada Mahasiswa Semester 6 Fakultas Kedokteran USU. Skripsi. Published online 2021.

8. Gunawan S, Sinsin I, Zani AYP. Hubungan Antara Pengetahuan dan Sikap dengan Perilaku Pencegahan COVID-19 Pada Peserta Seminar Online STIKes Raflesia 7 April 2020.
Perilaku dan Promosi Kesehat Indones Jurnal Health Promotion Behavior. 2021;3(1):47. doi:10.47034/ppk.v3i1.4553

9. Sari RK. Identifikasi Penyebab Ketidakpatuhan Warga Terhadap Penerapan Protokol Kesehatan 3M Di Masa Pandemi COVID-19. J Akrab Juara. 2021;6(1):84-94.

10. Surtimanah T, Sjamsuddin IN, Hanifah H, Alfianita D, Audia SS, Mulyawan P. Perilaku Pencegahan dan Sumber Informasi COVID-19 di Pedesaan dan Perkotaan Prevention Behavior and Information Sources of COVID-19 in Rural and Urban Areas. Afiasi - Jurnal Kesehatan Masyarakat. 2021;6(2):8293.

11. Fauzan Alfikri, Ali Akbar YDA. Pengetahuan dan Sikap Mahasiswa dalam Pencegahan COVID-19. Borneo Nursing Journal. 2021;3(1):1-9. http://www.informaticsjournals.com/in dex.php/jhsr/article/view/8530/13618

12. Komite Penanganan COVID-19. FINAL_Pedoman Pembelajaran pada Semester Genap TA 2020_2021_20201120.pdf. Pedoman Pembelajaran pada Semester Genap Tahun Ajaran 2020/2021 di Masa Pandemi COVID-19. Published online 2020:14. 